\title{
Study of Potassium Silicate and Silica Solubilizing Bacteria and its Impact on Yield and Quality of Sugarcane under Water Stress Condition
}

\author{
R. Anitha ${ }^{1 *}$, G. Gayathry ${ }^{2}$, S. Thiruvarasan ${ }^{3}$, P. Christy Nirmala Mary ${ }^{4}$ \\ and M. Jayachandran ${ }^{5}$
}
${ }^{1}$ Department of Crop Physiology, ${ }_{5}^{2}$ Department of Microbiology, ${ }^{3}$ Department of Agronomy, ${ }^{4}$ Department of Soil Science, ${ }^{5}$ Department of Agronomy, Sugarcane Research Station, Cuddalore, Tamil Nadu Agricultural University, Coimbatore, India

*Corresponding author

\begin{tabular}{|l|}
\hline Ke y w or d s \\
Silicon, Physiology, \\
Sugarcane, Quality, \\
Yield \\
\hline Article Info \\
\hline Accepted: \\
12 October 2019 \\
Available Online: \\
10 November 2019 \\
\hline
\end{tabular}

\section{A B S T R A C T}

The present investigation was carried out at Sugarcane Research Station, Cuddalore on CoC25 sugarcane variety during the period of 2016-2019. This study was conducted to determine the effect of silicon nutrition on physiology, yield and quality of sugarcane under drought condition. Result showed that soil application of silica solublizer @ $12.5 \mathrm{~kg}+50 \mathrm{~kg}$ FYM/ha + sett treatment with $0.5 \% \mathrm{~K}_{2} \mathrm{SiO}_{3}+2.5 \%$ urea and potash foliar spray on 15 days interval from 60 to 150 DAP showed maximum germination percentage, tiller population, leaf area, millable canes, relative water content, silica solubilizing microbial count, total chlorophyll content, nitrate reductase activity, catalase, proline, plant height, number of nodes, internode length, silicon content, carbon content, potassium content, single cane weight, commercial cane sugar per cent, cane yield and sugar yield under drought condition in both plant and ratoon crop.

\section{Introduction}

Sugarcane is an important cash crop \& plays an important role in the country's Agricultural economy. But day by day due to various reasons sugarcane productivity is going down, on the other side, production cost is increasing heavily due to increase in fertilizer cost, Labour cost, electricity charges, etc. Deteriorating soil health is also one of the concerns of low cane yields. Sugarcane is silicon ( $\mathrm{Si}$ ) accumulating crop and responds 
very well for silicon fertilization. Deficiency of silicon to sugarcane is also one of the prime reasons for low cane yields \& low sugar recovery. Silicon $(\mathrm{Si})$ is abundantly available Nutrient in the Earth's crust \& is second to oxygen. Its content in soils varies greatly and ranges from less than $01 \%$ to $45 \%$ by dry weight. Silicon is supposed to be beneficial element for the plants \& not as an essential element. However $\mathrm{Si}$ has enhanced the growth, development \& yield of many crops. The content of Si in many plants is more than $\mathrm{N}, \mathrm{P} \& \mathrm{~K}$ supplied through fertilizers. Sugarcane being Si accumulating crop and it absorbs silicon more than N, P \& K. Normally 12 month old sugarcane crop of $100 \mathrm{MT} / \mathrm{ha}$ absorbs about $400 \mathrm{Kg}$ of $\mathrm{Si} ; 205 \mathrm{Kg}$ of $\mathrm{N} ; 55$ $\mathrm{kg}$ of $\mathrm{P}$ and $275 \mathrm{Kg}$ of $\mathrm{K}$ per ha. It has been observed that one of the reasons for low yields of sugarcane is lack of Si fertilization to the crop. The productivity of sugarcane depends on mainly soil fertility, cane variety, Number of tillers, cane weight, water management, use of organic \& chemical fertilizers in balance proportion, management of pests \& diseases, time of harvesting etc. It is an essential element in high yielding plant species like rice, sugarcane, cereals, legumes, vegetables, tree crops and some leafy ornamentals and many plants species. However it may be observed in limiting levels under some growing conditions. Without Silicon these plants may suffer in a similar way to any plant suffer from a major or micro-nutrient deficiency but the signs are not as evident. Silicon deficiency reduced photosynthesis, low Brix, increased disease attack and insect, increased sunburn and wilting, enhanced postharvest fall are all signs of stress.

Silicon observed to be beneficial to plants where high levels of some nutrients content e.g. manganese and iron may be present in the soil. Silicon will alleviate the reinforcement of these elements in plant tissue preventing tissue damage. Researchers have shown that Silicon have a positive effect on yield quality and quantity. This might be due to its role in ethylene inhibition, which reduces the speed of aging and death of harvested plant parts. Silicon also have a good effect on plants chlorophyll content and help plants to maintain over a longer period with better shelf life and appearance. Potassium silicate foliar application has many benefits in improving leaf erectness, and improving photosynthesis efficiency also reducing capability to lodging in grasses. In addition, it offers benefits in many agricultural applications e.g. increases growth and yield, improves strength, minimize climate stress and provides impedance to mineral stress. The great attention in this study is to show the best method and rate of adding liquid potassium silicate using foliar application and observe its effect on some growth parameters, some macro and micro nutrients content and the fodder yield of maize plants.

Chen et al.,(2010) found that applying $1.5 \mathrm{mM}$ silicon to drought-stressed rice increased transpiration rate from $19 \%$ in a droughtsusceptible line and 53\% in a drought-resistant line. According to Shen et al., (2010), $1.7 \mathrm{mM}$ silicon increased leaf relative water content from $62.3 \%$ to $80.7 \%$, and transpiration by $29 \%$ in hydroponic soybean seedlings subjected to polyethylene glycol stress. According to Sonobe et al., (2010), $1.78 \mathrm{mM}$ $\mathrm{Si}\left(\mathrm{SiO}_{2}\right)$ in a $15 \%$ PEG $6000(\mathrm{v} / \mathrm{v})$ solution (to create $-0.6 \mathrm{MPa})$ at 23 days increased root water uptake and root water content, even with decreased osmotic potential of roots. Ahmed et al., (2011) conclude that "silicon application may be useful to improve the drought tolerance of sorghum through the enhancement of water uptake ability.

To ascertain the interaction effect of basal silicon incorporation, setts dipping in silicon solution and foliar spraying of urea and potash on cane productivity under drought situations. 
The application rate of silicon for alleviation of detrimental effects of drought on sugarcane.

\section{Materials and Methods}

Field experiments were conducted during the early season of 2016 to 2019 at Sugarcane Research Station, Cuddalore to evaluate the interaction effect of silicon incorporation as basal dress, setts dipping in silicon solution and foliar spraying of urea and potash on cane productivity under drought situations. The clone $\mathrm{CoC} 25$ was selected as test variety the soil of the experimental site was sandy loam in texture with low available nitrogen of $73 \mathrm{~kg} / \mathrm{ac}$, higher available phosphorus of $11 \mathrm{~kg} / \mathrm{ac}$, higher available potassium of $120 \mathrm{~kg} / \mathrm{ac}$, available micro nutrients of Fe of $18.35 \mathrm{ppm}$, $\mathrm{Mn}$ of $10.46 \mathrm{ppm}, \mathrm{Zn}$ of $0.78 \mathrm{ppm}, \mathrm{Cu}$ of 1.72 ppm present in the soil, $\mathrm{pH}$ of 7.6 and the EC of $0.12 \mathrm{dSm}^{-1}$. In water sample $\mathrm{pH} 6.3, \mathrm{EC}$ of $3.8 \mathrm{dSm}^{-1}, \mathrm{HCO}_{3}$ of $13.4 \mathrm{meq} / \mathrm{l}, \mathrm{Cl}$ of $24.3 \mathrm{meq} / 1, \mathrm{SO}_{4}$ of $0.3 \mathrm{meq} / \mathrm{l}, \mathrm{Ca}$ of $6.0 \mathrm{meq} / \mathrm{l}$, $\mathrm{Mg}$ of $7.0 \mathrm{meq} / \mathrm{l}, \mathrm{Na}$ of $20.0 \mathrm{meq} / 1, \mathrm{~K}$ of 5.0 meq/l, SAR of 7.84, Mg:Ca of 1.17. After the imposement of stress evading treatments the setts were transplanted to the main field. Regarding NPK fertilization, while the entire quantity of phosphorus was applied as basal, the doses of phosphorus and potassium were applied in 3 equal splits on 30 and 60 days after planting. $\mathrm{T}_{1}$-Control (imposing of stress for 9 times i.e., once in 15 days interval from 60 to $150 \mathrm{DAP}), \mathrm{T}_{2}-\mathrm{T}_{1}+2.5 \%$ urea and potash foliar spray on 15 days interval from 60 to 150 DAP, $\mathrm{T}_{3}-\mathrm{T}_{1}+$ Sett treatment of $0.5 \mathrm{mM} \mathrm{CaSiO}_{3}$ alone, $\mathrm{T}_{4}-\mathrm{T}_{1}+$ Sett treatment of $0.5 \% \mathrm{~K}_{2} \mathrm{SiO}_{3}$ alone, $\mathrm{T}_{5}-\mathrm{T}_{1}+$ Soil application of silica solublizer@12.5 kg+50kg FYM/ha, $\mathrm{T}_{6-} \mathrm{T}_{1}+$ Soil application of silica solublizer @ 12.5 $\mathrm{kg}+50 \mathrm{~kg} \mathrm{FYM} / \mathrm{ha}+$ Sett treatment of $0.5 \mathrm{mM}$ $\mathrm{CaSiO}_{3}$ alone $+2.5 \%$ urea and potash foliar spray on 15 days interval from 60 to 150 DAP, $\mathrm{T}_{7}-\mathrm{T}_{1}+$ Soil application of silica solublizer @ $12.5 \mathrm{~kg}+50 \mathrm{~kg} \mathrm{FYM} / \mathrm{ha}+$ Sett treatment of $0.5 \% \mathrm{~K}_{2} \mathrm{SiO}_{3}$ alone $+2.5 \%$ urea and potash foliar spray on 15 days interval from 60 to 150 DAP.

(Note: Water stress was imposed by withholding irrigation at critical period of 60150DAP for scheduling of irrigations once in 15 days)

All the crop management practices were adopted for all the treatment plots. The data on germination, tiller population, leaf area, millable canes, relative water content, silica solubilizing microbial count, total chlorophyll content, nitrate reductase activity, catalase, proline, plant height, number of nodes, internode length, single cane weight, commercial cane sugar per cent, cane yield and sugar yield were documented and presented in Tables 1, 2, 3 and 4.

\section{Sett treatment with silica solubilizer}

The biofertilizer, namely silica solubilizer was obtained from the Department of Microbiology, Agricultural College and Research Institute, Madurai. Soil application was performed with silica solubilizer@12.5 $\mathrm{kg} / \mathrm{ha}$ along with $50 \mathrm{~kg}$ of FYM / ha.

\section{Silica solubilising bacterial count}

Ashby's agar medium was used to enumerate the population of silica solubilizing bacteria by following spread plate procedure. The silica solubilizing potential of the bacteria picked out from the total silica solubilizing bacterial count plate

\section{Scanned electronic image protocol for silicon content in sugarcane leaves}

Leaves of each sugarcane plant were sectioned and immersed in karnovsky fixative solution in Eppendorf tubes for 24 hours. Immediately after fixation, the solutions were transferred to a cryoprotective solution (30\% glycerol) for 
30 minutes. The samples were then frozen in liquid nitrogen and fragmented with a scalpel on a cooled metal surface. The fragments were subsequently placed in petri dishes containing distilled water, dried on paper towels and then fixed with double-sided carbon tape onto a stub specimen holder (brass disc $12-13 \mathrm{~mm}$ (0.5 in diameter) wrapped in aluminum foil. Some fragments were fixed with the abaxial leaf surface facing up, while others were fixed with the abaxial side down. The stubs containing the specimens were placed in a desiccator's contain silica gel, and after three days, the stub- mounted samples were placed in a Balzers SCD 050 evaporator for plating (covering of the samples with gold). Same analysis was performed using a LEO EVO 40XVP scanning electron microscope. Several images at different magnifications were generated and digitally recorded. Photo paint software in the Corel Draw 12 package will be used for image preparation. The documented data on various observations were analyzed statistically (Fig. 1-4).

\section{Results and Discussion}

Soil application of silica solublizer @ 12.5 $\mathrm{kg}+50 \mathrm{~kg} \mathrm{FYM} / \mathrm{ha}+$ sett treatment with $0.5 \%$ $\mathrm{K}_{2} \mathrm{SiO}_{3}+2.5 \%$ urea and potash foliar spray on 15 days interval from 60 to 150 DA Precorded higher germination of $83.05 \%$.Abro et al., (2009) also documented similar report in wheat crop. This treatment also significantly registered the maximum mean tiller population of $1,48,354 / \mathrm{ha}$ and $1,47,852 / \mathrm{ha}$ in plant and ratoon crops respectively and it is on par with soil application of silica solublizer @ $12.5 \mathrm{~kg}+50 \mathrm{~kg} \mathrm{FYM} / \mathrm{ha}+$ sett treatment with $0.5 \mathrm{mM} \mathrm{CaSiO}_{3}+2.5 \%$ urea and potash foliar spray on 15 days interval from 60 to 150 DAP with $1,47,167 /$ ha and $1,45,234 /$ ha in respective crops. The control recorded the minimum mean tiller population of $1,07,784 / \mathrm{ha}$ and $1,03,342 / \mathrm{ha}$ in plant and ratoon crops respectively. The results are consistent with findings of Zhu et al., (2004) who have reported that $\mathrm{Si}$ effect was time-dependent and became significant when the crop advances. The level of polysaccharides in the cell wall was higher in the leaves containing Si than in those lacking Si.

Among the evaluated treatments the soil application of silica solublizer @ 12.5 $\mathrm{kg}+50 \mathrm{~kg} \mathrm{FYM} / \mathrm{ha}+$ sett treatment with $0.5 \%$ $\mathrm{K}_{2} \mathrm{SiO}_{3}+2.5 \%$ urea and potash foliar spray on 15 days interval from 60 to 150 DAP significantly registered the maximum mean plant height of $435 \mathrm{~cm}$ and $453.23 \mathrm{~cm}$ in plant and ratoon crops respectively and it is on par with soil application of silica solublizer @ $12.5 \mathrm{~kg}+50 \mathrm{~kg} \mathrm{FYM} / \mathrm{ha}+$ sett treatment with $0.5 \mathrm{mM} \mathrm{CaSiO}_{3}+2.5 \%$ urea and potash foliar spray on 15 days interval from 60 to 150 DAP with plant height of $427 \mathrm{~cm}$ and $431.56 \mathrm{~cm}$ in plant and ratoon crops respectively. It was comparable with the control recorded the minimum mean plant height of $380 \mathrm{~cm}$ and $360 \mathrm{~cm}$ in plant and ratoon crops respectively. This study also found that drought stress postponed the plant growth due to reduction of photosynthesis effects. It was because of stomatal closure and reduction of water entrance into the plant ultimately caused reduction in plant height. With the increase in silicon level dry weight, height of the plant and number of tillers were increased in the rice plants (Gerami et al., 2013).

The soil application of silica solublizer @ 12.5 $\mathrm{kg}+50 \mathrm{~kg} \mathrm{FYM} / \mathrm{ha}+$ sett treatment with $0.5 \%$ $\mathrm{K}_{2} \mathrm{SiO}_{3}+2.5 \%$ urea and potash foliar spray on 15 days interval from 60 to 150 DAP significantly registered the maximum mean number of buds of 23.00 and 25.23 in plant and ratoon crops respectively and it is on par with soil application of silica solublizer @ $12.5 \mathrm{~kg}+50 \mathrm{~kg} \mathrm{FYM} / \mathrm{ha}+$ sett treatment with $0.5 \mathrm{mM} \mathrm{CaSiO}_{3}+2.5 \%$ urea and potash foliar spray on 15 days interval from 60 to 150 DAP with 22.02 and 23.67 in plant and ratoon crops 
respectively. The control recorded the minimum mean number of buds of 17.67 and 16.98 in plant and ratoon crops respectively.

The soil application of silica solublizer @ 12.5 $\mathrm{kg}+50 \mathrm{~kg} \mathrm{FYM} / \mathrm{ha}+$ sett treatment with $0.5 \%$ $\mathrm{K}_{2} \mathrm{SiO}_{3}+2.5 \%$ urea and potash foliar spray on 15 days interval from 60 to 150 DAP significantly registered the maximum mean internode length of $13.03 \mathrm{~cm}$ and $13.42 \mathrm{~cm}$ in plant and ratoon crops respectively and it is on par with soil application of silica solublizer @ $12.5 \mathrm{~kg}+50 \mathrm{~kg}$ FYM/ha + sett treatment with $0.5 \mathrm{mM} \mathrm{CaSiO}_{3}+2.5 \%$ urea and potash foliar spray on 15 days interval from 60 to 150 DAP with $12.85 \mathrm{~cm}$ and $12.98 \mathrm{~cm}$ in plant and ratoon crops respectively. The control recorded the minimum mean internode length of $11.13 \mathrm{~cm}$ and $10.56 \mathrm{~cm}$ in plant and ratoon crops respectively.

Soil application of silica solublizer @ 12.5 $\mathrm{kg}+50 \mathrm{~kg} \mathrm{FYM} / \mathrm{ha}+$ sett treatment with $0.5 \%$ $\mathrm{K}_{2} \mathrm{SiO}_{3}+2.5 \%$ urea and potash foliar spray on 15 days interval from 60 to 150 DAP significantly improved $\mathrm{Si}, \mathrm{C}$ and $\mathrm{K}$ contents of $7.6 \%, 65.6 \%$ and $3.5 \%$ respectively.

The results obtained from mean comparisons for silicon contents were affected by all different rates of potassium silicate which showed that silicon application caused a significant increase in silicon concentrations. Similar results were observed by Morsy et al.,(2013) and Jafarei et al., (2015) who reported similar results in wheat and bean plants and stated that with the usage of silicon, amount of silicon absorption increases in plant.

Silicon content in leaves of the plants was found to be high due to sett treatment of potassium silicate. Similar results were noticed by Salim et al., (2013) who observed that potassium silicate increased mineral nutrients ( $\mathrm{N}, \mathrm{P}, \mathrm{K}, \mathrm{Ca}, \mathrm{Mg}, \mathrm{Zn}, \mathrm{Mn}$ and $\mathrm{Fe}$ ) in wheat leaves. This might be attributed to the promotion effect of $\mathrm{Si}$ in translocation of those nutrients including $\mathrm{Cu}, \mathrm{Mo}$ and $\mathrm{B}$ to the growing parts of the plant and which could enhance the growth of sugarcane as found by Huang et al., (2011). The control recorded the minimum $\mathrm{Si}, \mathrm{C}$ and $\mathrm{K}$ of $0.2 \%, 51.7 \%$ and $0.5 \%$ in plant crop respectively.

Among the evaluated treatments the soil application of silica solublizer @ 12.5 $\mathrm{kg}+50 \mathrm{~kg} \mathrm{FYM} / \mathrm{ha}+$ sett treatment with $0.5 \%$ $\mathrm{K}_{2} \mathrm{SiO}_{3}+2.5 \%$ urea and potash foliar spray on 15 days interval from 60 to 150 DAP significantly registered the maximum mean single cane weight of $1656 \mathrm{~g}$ and $1633 \mathrm{~g}$ in plant and ratoon crops respectively which might be attributed to the effect of soil application of silica solublizer and accumulation of photosynthates was comparable with soil application of silica solublizer@12.5 kg+50kg FYM/ha + sett treatment with $0.5 \mathrm{mM} \mathrm{CaSiO}+2.5 \%$ urea and potash foliar spray on 15 days interval from 60 to 150 DAP with $1517 \mathrm{~g}$ and $1595 \mathrm{~g}$ in plant and ratoon crops respectively.

The control recorded the minimum mean single cane weight of $1167 \mathrm{~g}$ and $1056 \mathrm{~g}$ in plant and ratoon crops respectively.

\section{Physiological indices}

\section{Leaf Area (cm) (Table 1)}

Among the treatments evaluated the soil application of silica solublizer @ 12.5 $\mathrm{kg}+50 \mathrm{~kg}$ FYM/ha + sett treatment with $0.5 \%$ $\mathrm{K}_{2} \mathrm{SiO}_{3}+2.5 \%$ urea and potash foliar spray on 15 days interval from 60 to 150 DAP significantly registered the maximum mean leaf area of $392.12 \mathrm{~cm}^{2}$ and $372.32 \mathrm{~cm}^{2}$ in plant and ratoon crops respectively.

Leaf area is the important in yield deciding indices since sugarcane with higher leaf area 
under ample sunlight resulted high photosynthetic efficiency under ample sunlight, compared to other crops. In line with this higher ethylene evolution led to higher leaf area which resulted in greater light interception and photosynthesis (Mir et al., 2010).

The soil application of silica solublizer @ 12.5 $\mathrm{kg}+50 \mathrm{~kg}$ FYM/ha stands next with the $379.38 \mathrm{~cm}^{2}$ and $369.34 \mathrm{~cm}^{2}$ in plant and ratoon crops respectively. The control recorded the minimum mean leaf area of $215.06 \mathrm{~cm}^{2}$ and $115.06 \mathrm{~cm}^{2}$ in plant and ratoon crops respectively.

\section{Relative water content (\%) (Table 1)}

Drought stress leads to closure of stomata and it subsequently decreased the photosynthetic rate. The RWC of leaves was used to assess cellular damage as indicated by the extent of dehydration. In this study, drought stress caused a decrease in RWC content, but $\mathrm{Si}$ application can alleviate water stress by decreasing the transpiration. Among the treatments the soil application of silica solublizer @ $12.5 \mathrm{~kg}+50 \mathrm{~kg}$ FYM/ha + sett treatment with $0.5 \% \mathrm{~K}_{2} \mathrm{SiO}_{3}+2.5 \%$ urea and potash foliar spray on 15 days interval from 60 to 150 DAP significantly registered the maximum mean relative water content of $89.64 \%$ and $86.62 \%$ in plant and ratoon crops respectively.

This result is in agreement with those of Lobato et al., (2009), who showed that an increase in the Si concentration promoted an increase in the water retention of pepper leaf tissue.

The control recorded the minimum mean relative water content of $72.85 \%$ and $78 \%$ in plant and ratoon crops respectively.
Silica solubilizing microbial count (Table 2)

The soil application of silica solublizer@12.5 $\mathrm{kg}+50 \mathrm{~kg} \mathrm{FYM} / \mathrm{ha}+$ sett treatment with $0.5 \%$ $\mathrm{K}_{2} \mathrm{SiO}_{3}+2.5 \%$ urea and potash foliar spray on 15 days interval from 60 to 150 DAP significantly registered the maximum mean microbial count of $27.89 \mathrm{cfu} \times 10^{5} /$ gand 28.76 cfu $\times 10^{5} /$ gin plant and ratoon crops respectively and it is on par with soil application of silica solublizer @ 12.5 $\mathrm{kg}+50 \mathrm{~kg} \mathrm{FYM} / \mathrm{ha}$ and soil application of silica solublizer@12.5 kg+50kg FYM/ha + sett treatment with $0.5 \mathrm{mM} \mathrm{CaSiO} 3+2.5 \%$ urea and potash foliar spray on 15 days interval from 60 to 150 DAP.

Soil contains a variety of micro- organisms but a few are capable of solubilizing silicates. Silicon plays two separate functions in root cell walls, strengthening the endodermal cell walls in the mature basal region and keeping the young expanding cell walls extensible in the apical region of the roots (Hattori et al., 2003). Hence its application seems to be quite beneficial to plants grown under drought conditions by encouraging the development of profuse root system and providing protection to roots against soil drying.

Moreover, the microbes like Bacillus Caldolytyicus, Bacillus Mucilaginosusvar Siliceous, Proteus Mirabilis, Pseudomonas and Penicillium were found to release silica from natural silicates.

The presence of $\mathrm{Si}$ in soil solution renders phosphorus and potassium availability to plants reversing its fixation as $\mathrm{Si}$ itself prefers for phosphorus fixation sites in the soil. The control recorded the minimum mean microbial count of $9.3 \mathrm{cfu} \times 10^{5} / \mathrm{g}$ and $10.35 \mathrm{cfu} \times 10^{5} / \mathrm{g}$ in plant and ratoon crops respectively. 
Table.1 Effect of silicon nutrients on growth and physiological parameters of sugarcane plant and ratoon crop under drought condition

\begin{tabular}{|c|c|c|c|c|c|c|c|c|c|}
\hline \multirow{2}{*}{$\begin{array}{c}\text { Treatments } \\
\mathbf{T}_{1}\end{array}$} & \multirow{2}{*}{$\begin{array}{c}\text { Germination } \\
\% \\
74.43\end{array}$} & \multicolumn{2}{|c|}{$\begin{array}{c}\text { Tiller } \\
\text { population (/ha) }\end{array}$} & \multicolumn{2}{|c|}{$\begin{array}{c}\text { Millable cane } \\
\text { population } \\
\text { (/ha) }\end{array}$} & \multicolumn{2}{|c|}{$\begin{array}{l}\text { Leaf Area } \\
\quad\left(\mathrm{cm}^{2}\right)\end{array}$} & \multicolumn{2}{|c|}{$\begin{array}{c}\text { Relative } \\
\text { water content } \\
(\%)\end{array}$} \\
\hline & & 107784 & 103342 & 92023 & 90345 & 215.06 & 115.06 & 72.85 & 78.00 \\
\hline $\mathbf{T}_{2}$ & 78.19 & 1172 & 1124 & 100501 & 10342 & 9 & 09 & 8 & .28 \\
\hline $\mathbf{T}_{3}$ & 80.43 & 129037 & 125435 & 107143 & 114576 & 247.36 & 297.36 & 81.30 & 80.30 \\
\hline $\mathbf{T}_{4}$ & 81.07 & 137941 & 138342 & 110238 & 122579 & 361.60 & 346.69 & 85.90 & 83.29 \\
\hline $\mathbf{T}_{5}$ & 75.28 & 146785 & 142356 & 109524 & 115643 & 379.38 & 369.34 & 85.57 & 82.59 \\
\hline $\mathbf{T}_{6}$ & 77.86 & 147167 & 145234 & 112345 & 123678 & 371.59 & 352.45 & 84.62 & 83.60 \\
\hline $\mathbf{T}_{7}$ & 83.05 & 148354 & 147852 & 126428 & 127845 & 392.12 & 372.32 & 89.64 & 86.62 \\
\hline CD & NS & 26954 & 24562 & 31656 & 28765 & 95.86 & 90.38 & 7.33 & 6.83 \\
\hline
\end{tabular}

Table.2 Effect of silicon nutrients on growth and physiological parameters of sugarcane plant and ratoon crop under drought condition

\begin{tabular}{|c|c|c|c|c|c|c|c|c|c|c|}
\hline \multirow[t]{2}{*}{$\begin{array}{l}\text { Treat } \\
\text { ments }\end{array}$} & \multicolumn{2}{|c|}{$\begin{array}{l}\text { Silica solublizer } \\
\text { microbial } \\
\text { countcfu/10 } \mathrm{g}^{-1}\end{array}$} & \multicolumn{2}{|c|}{$\begin{array}{c}\text { Total } \\
\text { Chlorophyll } \\
\text { mgg }^{-1} \\
\end{array}$} & \multicolumn{2}{|c|}{$\begin{array}{l}\text { Nitrate Reductase } \\
\text { activity } \\
\text { mg of } \mathrm{NO}_{2} \mathrm{~g}^{-1} \mathbf{h r}^{-1}\end{array}$} & \multicolumn{2}{|c|}{$\begin{array}{c}\text { Catalase } \\
\mu \mathrm{g} \text { of } \mathrm{H}_{2} \mathrm{O}_{2} \mathrm{~g}^{-1} \\
\text { of tissue }\end{array}$} & \multicolumn{2}{|c|}{$\begin{array}{c}\text { Proline } \\
\mu^{-1} \text { of tissue }\end{array}$} \\
\hline & $\begin{array}{l}\text { Plant } \\
\text { crop I }\end{array}$ & $\begin{array}{l}\text { Plant } \\
\text { crop II }\end{array}$ & $\begin{array}{l}\text { Plant } \\
\text { crop }\end{array}$ & $\begin{array}{l}\text { Ratoo } \\
\text { n crop }\end{array}$ & $\begin{array}{l}\text { Plant } \\
\text { crop }\end{array}$ & $\begin{array}{c}\text { Ratoon } \\
\text { crop }\end{array}$ & $\begin{array}{l}\text { Plant } \\
\text { crop }\end{array}$ & $\begin{array}{l}\text { Ratoon } \\
\text { crop }\end{array}$ & $\begin{array}{l}\text { Plant } \\
\text { crop }\end{array}$ & $\begin{array}{l}\text { Ratoo } \\
\text { n crop }\end{array}$ \\
\hline$T_{1}$ & 9.30 & 10.35 & 0.0192 & 0.0185 & 62.18 & 59.78 & 7.41 & 9.12 & 196.68 & 178.08 \\
\hline $\mathbf{T}_{2}$ & 14.80 & 16.80 & 0.0232 & 0.0214 & 71.37 & 87.65 & 6.78 & 7.73 & 230.02 & 236.22 \\
\hline $\mathbf{T}_{3}$ & 17.43 & 18.77 & 0.0240 & 0.0221 & 93.95 & 98.76 & 6.46 & 7.46 & 222.75 & 232.15 \\
\hline$T_{4}$ & 18.03 & 19.03 & 0.0236 & 0.0243 & 101.09 & 116.45 & 6.65 & 6.55 & 235.35 & 236.38 \\
\hline $\mathbf{T}_{5}$ & 27.23 & 25.23 & 0.0242 & 0.0253 & 113.25 & 123.34 & 6.56 & 7.56 & 334.68 & 338.18 \\
\hline$T_{6}$ & 25.67 & 25.85 & 0.0283 & 0.0321 & 124.87 & 127.38 & 6.14 & 7.18 & 338.20 & 340.25 \\
\hline $\mathbf{T}_{7}$ & 27.89 & 28.76 & 0.0364 & 0.0372 & 136.35 & 134.39 & 5.82 & 6.22 & 352.31 & 352.10 \\
\hline CD & 9.02 & 8.97 & 0.01 & 0.009 & 8.28 & 6.23 & 0.08 & 0.68 & 3.46 & 2.86 \\
\hline
\end{tabular}


Table.3 Effect of silicon nutrients on growth and physiological parameters of sugarcane plant and ratoon crop at harvest stage under field condition

\begin{tabular}{|c|c|c|c|c|c|c|c|c|c|}
\hline \multirow[t]{2}{*}{ Treatments } & \multicolumn{2}{|c|}{ Plant height (cm) } & \multicolumn{2}{|c|}{ Number of buds } & \multicolumn{2}{|c|}{$\begin{array}{c}\text { Internodal length } \\
(\mathbf{c m})\end{array}$} & \multicolumn{3}{|c|}{$\begin{array}{l}\text { Macro nutrients } \\
\text { and Si content }\end{array}$} \\
\hline & $\begin{array}{l}\text { Plant } \\
\text { crop }\end{array}$ & $\begin{array}{l}\text { Ratoon } \\
\text { crop }\end{array}$ & $\begin{array}{l}\text { Plant } \\
\text { crop }\end{array}$ & $\begin{array}{l}\text { Ratoon } \\
\text { crop }\end{array}$ & $\begin{array}{l}\text { Plant } \\
\text { crop }\end{array}$ & $\begin{array}{l}\text { Ratoon } \\
\text { crop }\end{array}$ & $\begin{array}{l}\mathrm{Si} \\
\%\end{array}$ & $\begin{array}{l}\mathrm{C} \\
\%\end{array}$ & $\begin{array}{l}\mathrm{K} \\
\%\end{array}$ \\
\hline$T_{1}$ & 380.00 & 360.23 & 17.67 & 16.98 & 11.13 & 10.56 & 0.2 & 51.7 & 0.5 \\
\hline $\mathbf{T}_{2}$ & 396.66 & 403.45 & 21.00 & 20.34 & 12.44 & 12.32 & 0.4 & 56.8 & 2.9 \\
\hline $\mathbf{T}_{3}$ & 400.00 & 421.25 & 18.33 & 19.29 & 12.36 & 12.54 & 0.6 & 60.7 & 1.4 \\
\hline $\mathbf{T}_{4}$ & 388.33 & 396.29 & 18.67 & 18.78 & 12.33 & 12.67 & 1.6 & 61.0 & 1.7 \\
\hline $\mathbf{T}_{5}$ & 403.33 & 423.08 & 20.00 & 22.54 & 12.55 & 12.38 & 2.7 & 61.2 & 0.6 \\
\hline$T_{6}$ & 427.00 & 431.56 & 22.02 & 23.67 & 12.85 & 12.98 & 4.7 & 63.8 & 2.1 \\
\hline $\mathbf{T}_{7}$ & 435.00 & 453.23 & 23.00 & 25.23 & 13.03 & 13.42 & 7.6 & 65.6 & 3.5 \\
\hline CD & 24.5 & 21.3 & 3.26 & 3.54 & 2.28 & 2.25 & & & \\
\hline
\end{tabular}

Table.4 Effect of silicon nutrients on yield parameters of sugarcane plant and ratoon crop at harvest stage under field condition

\begin{tabular}{|c|c|c|c|c|c|c|c|c|}
\hline Treatments & \multicolumn{2}{|c|}{$\begin{array}{c}\text { Single cane } \\
\text { weight }(\mathbf{g})\end{array}$} & \multicolumn{2}{c|}{ Cane yield (t/ha) } & \multicolumn{2}{c|}{ CCS (\%) } & \multicolumn{2}{c|}{$\begin{array}{c}\text { Sugar yield } \\
\text { (t/ha) }\end{array}$} \\
\hline & $\begin{array}{c}\text { Plant } \\
\text { crop }\end{array}$ & $\begin{array}{c}\text { Ratoon } \\
\text { crop }\end{array}$ & $\begin{array}{c}\text { Plant } \\
\text { crop }\end{array}$ & $\begin{array}{c}\text { Ratoon } \\
\text { crop }\end{array}$ & $\begin{array}{c}\text { Plant } \\
\text { crop }\end{array}$ & $\begin{array}{c}\text { Ratoon } \\
\text { crop }\end{array}$ & $\begin{array}{c}\text { Plant } \\
\text { crop }\end{array}$ & $\begin{array}{c}\text { Ratoon } \\
\text { crop }\end{array}$ \\
\hline $\mathbf{T}_{\mathbf{1}}$ & 1167 & 1056 & 92.61 & 72.42 & 10.30 & 9.96 & 9.32 & 8.26 \\
\hline $\mathbf{T}_{\mathbf{2}}$ & 1467 & 1324 & 117.89 & 114.30 & 10.73 & 10.12 & 12.60 & 13.59 \\
\hline $\mathbf{T}_{\mathbf{3}}$ & 1383 & 1564 & 118.62 & 126.40 & 10.42 & 10.89 & 13.58 & 15.11 \\
\hline $\mathbf{T}_{\mathbf{4}}$ & 1500 & 1532 & 117.90 & 117.34 & 10.57 & 10.26 & 14.32 & 13.01 \\
\hline $\mathbf{T}_{\mathbf{5}}$ & 1417 & 1489 & 121.55 & 122.70 & 10.53 & 11.12 & 15.11 & 15.18 \\
\hline $\mathbf{T}_{\mathbf{6}}$ & 1517 & 1595 & 125.94 & 123.32 & 11.08 & 11.56 & 14.76 & 14.73 \\
\hline $\mathbf{T}_{\mathbf{7}}$ & 1656 & 1633 & 128.52 & 127.37 & 11.78 & 11.84 & 15.26 & 15.39 \\
\hline $\mathbf{C D}$ & $\mathbf{3 8 4 . 9}$ & $\mathbf{3 9 3 . 0}$ & $\mathbf{5 . 8 7}$ & $\mathbf{6 . 6 3}$ & $\mathbf{0 . 3 8}$ & $\mathbf{0 . 5 4}$ & $\mathbf{0 . 9 2}$ & $\mathbf{0 . 8 8}$ \\
\hline
\end{tabular}


Fig.1 Effect of silicon nutrition on growth of sugarcane crop at germination stage under drought condition

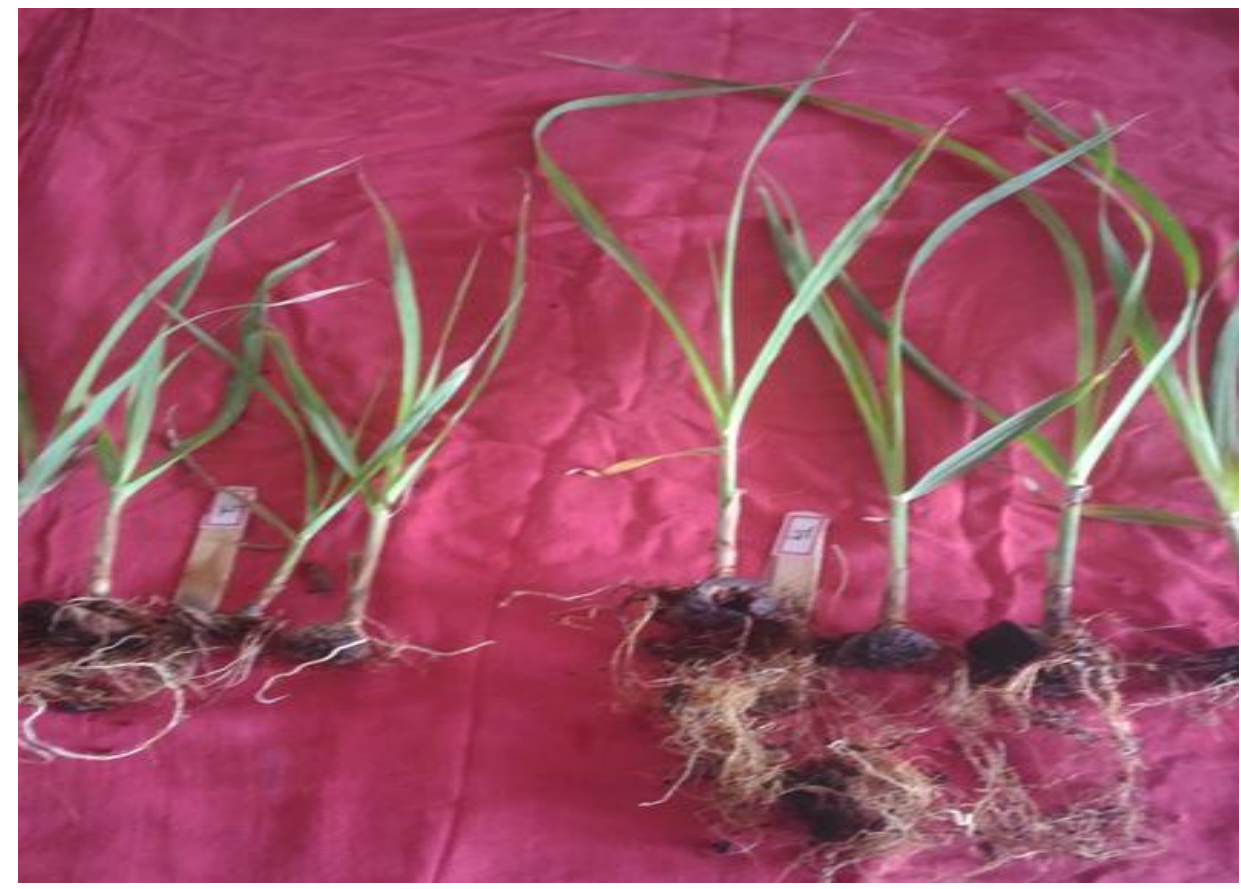

Fig.2 Silica solubilizing potential of silica solubilizer in Ashby's agar medium. The diameter of the clearing zone formed was $3.2 \mathrm{~cm}$

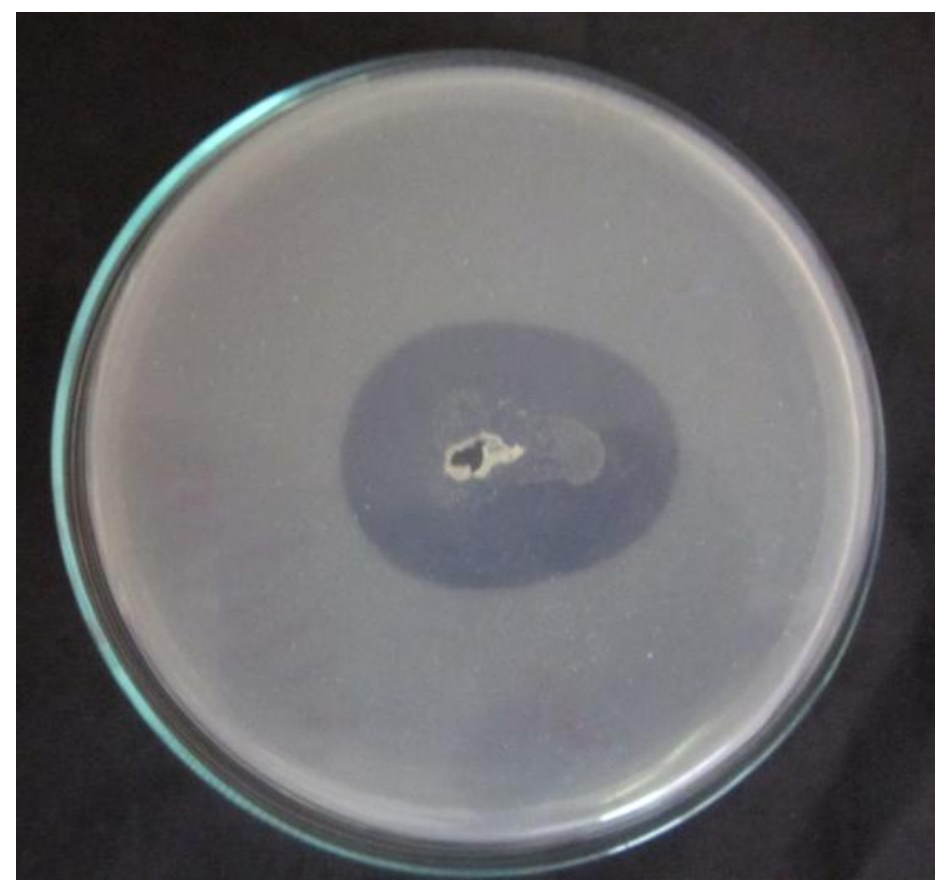


Fig.3 Effect of silicon nutrition on growth of sugarcane crop on Silicon, Carbon and Potassium content through SEM image under drought condition
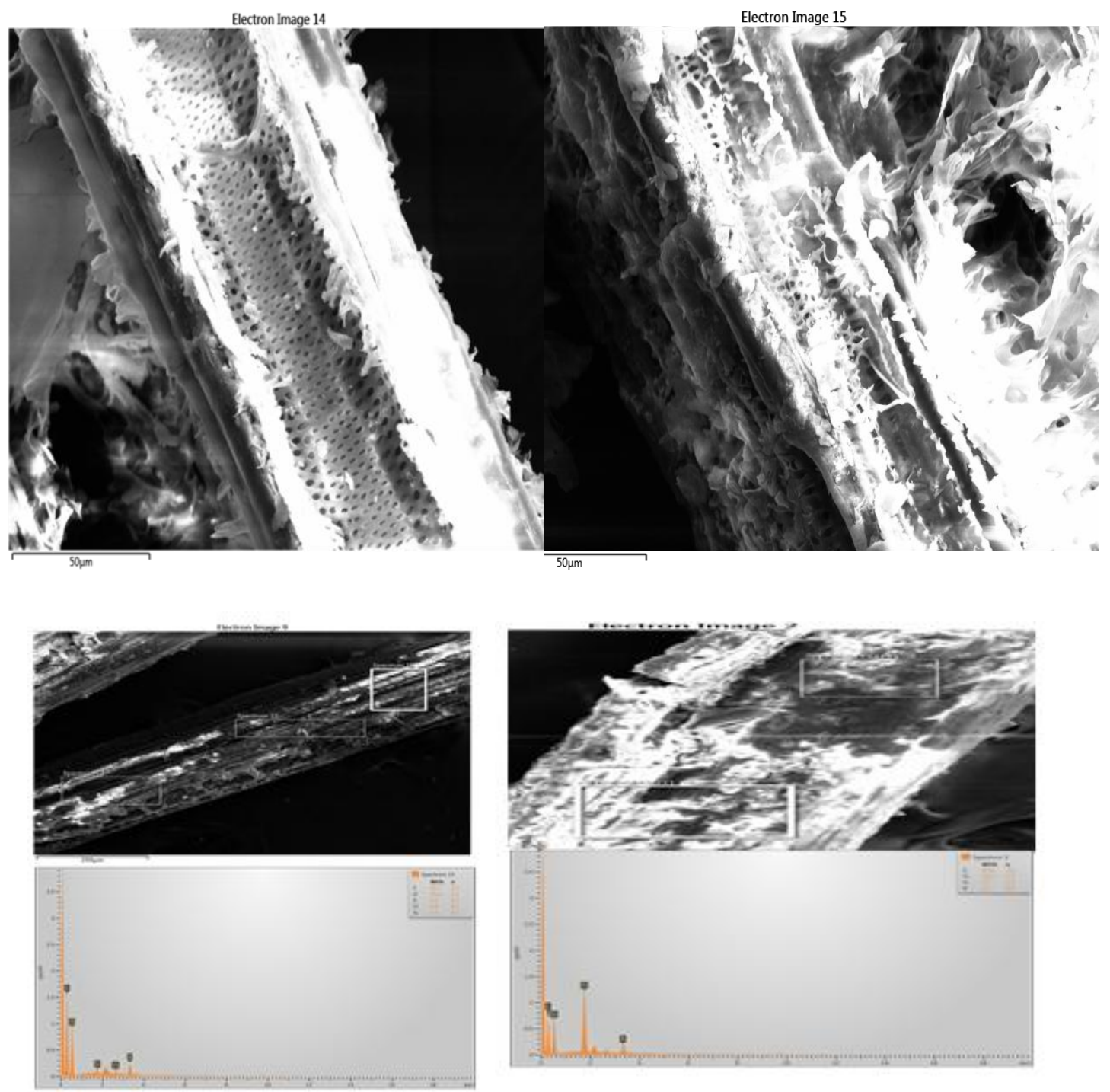

Control

Soil application of silica solublizer@12.5kg along with $50 \mathrm{~kg} \mathrm{FYM} / \mathrm{ha}+$ sett treatment of $0.5 \% \mathrm{~K} 2 \mathrm{SiO} 3$ alone $+2.5 \%$ urea and potash foliar spray on 15 days interval from 60 to 150 DAP 
Fig.4 Effect of silicon nutrition on growth of sugarcane crop at harvest stage under drought condition

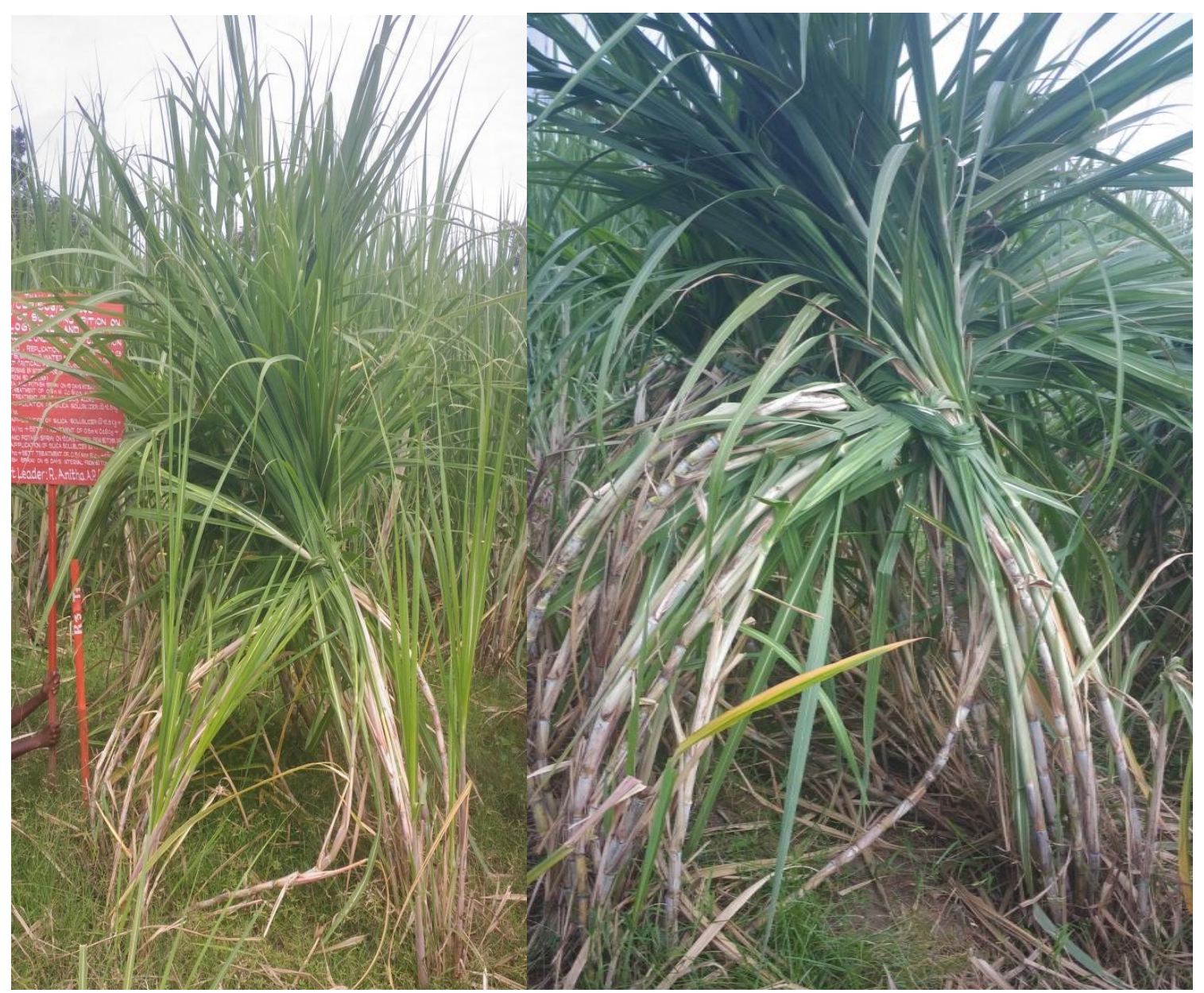

\section{Total chlorophyll content (mg/g) (Table 2)}

Among the treatments, the soil application of silica solublizer@12.5 kg+50kg FYM/ha + sett treatment with $0.5 \% \mathrm{~K}_{2} \mathrm{SiO}_{3}+2.5 \%$ urea and potash foliar spray on 15 days interval from 60 to 150 DAP significantly registered the maximum mean total chlorophyll content of $0.0364 \mathrm{mg} / \mathrm{g}$ and $0.0372 \mathrm{mg} / \mathrm{g}$ in plant and ratoon crops respectively and it is on par with soil application of silica solublizer @ 12.5 $\mathrm{kg}+50 \mathrm{~kg} \mathrm{FYM} / \mathrm{ha}+$ sett treatment with $0.5 \mathrm{mM} \mathrm{CaSiO} 3+2.5 \%$ urea and potash foliar spray on 15 days interval from 60 to 150 DAP with $0.0283 \mathrm{mg} / \mathrm{g}$ and $0.0321 \mathrm{mg} / \mathrm{g}$ of chlorophyll in respective crops. $\mathrm{Si}$ could increase the photosynthesis of wheat plants under drought and this might be associated with the enhancement in activities of photosynthetic enzymes and chlorophyll content under stress conditions ( $\mathrm{Li}$ et al., 2007) and sorghum (Hattori et al., 2005).

Further, Kaufman et al., (1979) found that Si as silica bodies deposited in leaf epidermis act as a "window" that enhances the light use efficiency by facilitating the transmission of light to the photosynthetic mesophyll tissues. Ahmed et al., (2011) also ascertained that increase in silicon leads to increase in leaf are index, specific leaf weight, chlorophyll content, leaf dry weight, root dry weight, total dry weight under stress in sorghum. The control recorded the minimum mean total 
chlorophyll content of $0.0192 \mathrm{mg} / \mathrm{g}$ and $0.0185 \mathrm{mg} / \mathrm{g}$ in plant and ratoon crops respectively.

\section{Catalase ( $\mu$ g of $\mathrm{H}_{2} \mathrm{O}_{2} / \mathrm{g}$ of tissue) (Table 2)}

Among the treatments, the soil application of silica solublizer @ $12.5 \mathrm{~kg}+50 \mathrm{~kg}$ FYM/ha + sett treatment with $0.5 \% \mathrm{~K}_{2} \mathrm{SiO}_{3}+2.5 \%$ urea and potash foliar spray on 15 days interval from 60 to 150 DAP significantly registered the minimum mean catalase content of 5.82 and $6.22 \mu \mathrm{g}$ of $\mathrm{H}_{2} \mathrm{O}_{2} / \mathrm{g}$ of tissue in both plant and ratoon crops respectively and it is on par with soil application of silica solublizer @ $12.5 \mathrm{~kg}+50 \mathrm{~kg} \mathrm{FYM} / \mathrm{ha}+$ sett treatment with $0.5 \mathrm{mM} \mathrm{CaSiO} 3+2.5 \%$ urea and potash foliar spray on 15 days interval from 60 to 150 DAP treatment. In metabolic processes plants produce $\mathrm{H}_{2} \mathrm{O}_{2}$ which causes damage to the cell oxidation function, while CAT can eliminate $\mathrm{H}_{2} \mathrm{O}_{2}$ and play a key role in the elimination of $\mathrm{O}_{2}$. The combined action of CAT and SOD converts the toxic $\mathrm{O}_{2}$ superoxide radical and $\mathrm{H}_{2} \mathrm{O}_{2}$ to water and molecular oxygen $\left(\mathrm{O}_{2}\right)$, thus averting the cellular damage under unfavourable conditions (Noctor et al., 2000). The control recorded the highest catalase content of 7.41 and $9.12 \mu \mathrm{g}$ of $\mathrm{H}_{2} \mathrm{O}_{2} / \mathrm{g}$ of tissue in plant and ratoon crops respectively.

\section{Nitrate Reductase activity (mg of $\mathrm{NO}_{2} / \mathrm{g} / \mathrm{hr}$ )} (Table 2)

Among the evaluated treatments the soil application of silica solublizer @ 12.5 $\mathrm{kg}+50 \mathrm{~kg} \mathrm{FYM} / \mathrm{ha}+$ sett treatment with $0.5 \%$ $\mathrm{K}_{2} \mathrm{SiO}_{3}+2.5 \%$ urea and potash foliar spray on 15 days interval from 60 to 150 DAP significantly registered the maximum mean nitrate reductase activityof 136.35 and 134.39 $\mathrm{mg}$ of $\mathrm{NO}_{2} / \mathrm{g} / \mathrm{hr}$ in plant and ratoon crops respectively. The control recorded the minimum mean nitrate reductase activity of 62.18 and $59.78 \mathrm{mg}$ of $\mathrm{NO}_{2} / \mathrm{g} / \mathrm{hr}$ in plant and ratoon crops respectively. The nitrate reductase (NRase) activity was drastically reduced in sugarcane cultivars under drought stress conditions. The lower NRase activity could probably be due to reduced storage pool size of $\mathrm{NO}_{3}$ and reduced $\mathrm{NO}_{3}$ flux from roots to leaves. The decrease in NRase activity in leaves by external supply of PEG may be related to osmotic changes following PEG addition into the medium.

\section{Proline content $(\mu \mathrm{g} / \mathrm{g})($ Table 2$)$}

Soil application of silica solublizer@12.5 $\mathrm{kg}+50 \mathrm{~kg} \mathrm{FYM} / \mathrm{ha}+$ sett treatment with $0.5 \%$ $\mathrm{K}_{2} \mathrm{SiO}_{3}+2.5 \%$ urea and potash foliar spray on 15 days interval from 60 to 150 DAP significantly registered the maximum mean proline content of 352.31 and $352.10 \mu \mathrm{g} / \mathrm{g}$ of tissue in plant and ratoon crops respectively. The control recorded the minimum mean proline content of 196.68 and $178.08 \mu \mathrm{g} / \mathrm{g}$ of tissue in plant and ratoon crops respectively. Crusciol et al., (2009) found that the application of $284.4 \mathrm{mg} \mathrm{dm}^{-3}$ of $\mathrm{Ca}$ and $\mathrm{Mg}$ silicates to the soil increased proline concentrations under drought conditions. The proline content of sugarcane plants showed an increasing trend after silicon application under drought situations. The accumulation of proline associated with stress might serve as a compatible solute in order to maintain the osmotic balance and allow the plants to acclimatize to unfavourable environment. Besides it also acts as a component of the antioxidative defense system rather than an osmotic adjustment mediator. Similar studies were also reported by Singh et al., (2006).

Among the treatments, the soil application of silica solublizer@12.5 kg+50kg FYM/ha + sett treatment with $0.5 \% \mathrm{~K}_{2} \mathrm{SiO}_{3}+2.5 \%$ urea and potash foliar spray on 15 days interval from 60 to 150 DAP significantly registered the maximum mean millable cane of $1,26,428 /$ ha and $1,27,845 /$ ha in plant and 
ratoon crops respectively and it is on par with soil application of silica solublizer @ 12.5 $\mathrm{kg}+50 \mathrm{~kg} \mathrm{FYM} / \mathrm{ha}+$ sett treatment with $0.5 \mathrm{mM} \mathrm{CaSiO}_{3}+2.5 \%$ urea and potash foliar spray on 15 days interval from 60 to 150 DAP with $1,12,345 /$ ha and $1,23,678$ /ha in respective crops.

The soil application of silica solublizer @ 12.5 $\mathrm{kg}+50 \mathrm{~kg} \mathrm{FYM} / \mathrm{ha}+$ sett treatment with $0.5 \%$ $\mathrm{K}_{2} \mathrm{SiO}_{3}+2.5 \%$ urea and potash foliar spray on 15 days interval from 60 to 150 DAP $\left(T_{7}\right)$ significantly registered the maximum cane yield of $128.52 \mathrm{t} / \mathrm{ha}$ and $127.37 \mathrm{t} / \mathrm{ha}$ in plant and ratoon crops respectively. However, it was on par with the soil application of silica solublizer@12.5 kg+50kg FYM/ha + sett treatment with $0.5 \mathrm{mM} \mathrm{CaSiO} 3+2.5 \%$ urea and potash foliar spray on 15 days interval from 60 to 150 DAP) with 125.94t/ha and $123.32 \mathrm{t} / \mathrm{ha}$ respectively in plant crop and in ratoon crops. The control recorded the minimum mean cane yield of $92.61 \mathrm{t} / \mathrm{ha}$ and $72.42 \mathrm{t} / \mathrm{ha}$ in plant and ratoon crops respectively.

These results agreement with Ren et al.,(2002) findings who found that $\mathrm{Si}$ application increased yield of sugarcane due to increased utilization rate and absorbing ability of nutrients. The yield increment attributed to the direct beneficial effects of $\mathrm{Si}$ such as vegetative growth, increase of chlorophyll content, photosynthetic activity of plant, protective enzymes and water metabolism and to some indirect effects such as acquisition of macro- and micronutrients.

Soil application of silica solublizer @ 12.5 $\mathrm{kg}+50 \mathrm{~kg} \mathrm{FYM} / \mathrm{ha}+$ sett treatment with $0.5 \%$ $\mathrm{K}_{2} \mathrm{SiO}_{3}+2.5 \%$ urea and potash foliar spray on 15 days interval from 60 to 150 DAP significantly registered the maximum mean commercial cane sugar of $11.78 \%$ and $11.84 \%$ in plant and ratoon crops respectively. However, it was on par with the soil application of silica solublizer @ 12.5 $\mathrm{kg}+50 \mathrm{~kg} \mathrm{FYM} / \mathrm{ha}+$ sett treatment with $0.5 \mathrm{mM} \mathrm{CaSiO}_{3}+2.5 \%$ urea and potash foliar spray on 15 days interval from 60 to 150 DAP with $11.08 \%$ and $11.56 \%$ and $2.5 \%$ urea and potash foliar spray on 15 days interval from 60 to 150 DAP with $10.73 \%$ and $10.12 \%$ respectively in plant crop and in ratoon crops. The control recorded the minimum CCS\% of $10.32 \%$ and $9.96 \%$ in plant and ratoon crops respectively.

Among the evaluated treatments soil application of silica solublizer @ 12.5 $\mathrm{kg}+50 \mathrm{~kg} \mathrm{FYM} / \mathrm{ha}+$ sett treatment with $0.5 \%$ $\mathrm{K}_{2} \mathrm{SiO}_{3}+2.5 \%$ urea and potash foliar spray on 15 days interval from 60 to 150 DAP significantly registered the maximum sugar yield of $15.26 \mathrm{t} / \mathrm{ha}$ and $15.39 \mathrm{t} / \mathrm{ha}$ in plant and ratoon crops respectively. However, it was on par with the soil application of silica solublizer@12.5 kg +50 kg FYM/ha with $15.11 \mathrm{t} /$ ha and $15.18 \mathrm{t} / \mathrm{ha}$ respectively in plant and ratoon crops. The control recorded the minimum mean sugar yield of $9.321 \mathrm{t} / \mathrm{ha}$ and $8.26 \mathrm{t} / \mathrm{ha}$ in respective crops.

Soil application of silica solublizer @ $12.5 \mathrm{~kg}$ $+50 \mathrm{~kg} \mathrm{FYM} / \mathrm{ha}+$ sett treatment with $0.5 \%$ $\mathrm{K}_{2} \mathrm{SiO}_{3}+2.5 \%$ urea and potash foliar spray on 15 days interval from 60 to 150 DAP increase the growth and physiological parameters of sugarcane and increase the cane productivity in terms of cane and sugar yield under drought situations.

\section{References}

Abro SA, Qureshi R, Soomro FM, Ahmed AM, Jakhar GS (2009). Effects of silicon levels on growth and yield of wheat in silty loam soil. Pak J Bot 41 (3): 1385-1390

Ahmed M, Hassen FU, Qadeer U, Aslam MA (2011). Silicon application and drought 
tolerance mechanism of sorghum. Afr J Agric Res 6 (3):594-607

Al-Aghabary K., Zhu Z., Shi Q. (2004). Influence of silicon supply on chlorophyll content, chlorophyll fluorescence and antioxidative enzyme activities in tomato plants under salt stress. Journal of Plant Nutrition, 27: 2101-2115.

Chen, W., X. Yao, K. Cai, and J. Chen. (2010). Silicon alleviates drought stress of rice

plants by improving plant water status, photosynthesis and mineral nutrient absorption. Biol. Trace. Elem. Res.

Crusciol, C.A.C., A.L. Pulz, L.B. Lemos, R.P. Soratto, and G.P.P. Lima. (2009). Effects of silicon and drought stress on tuber yield and leaf biochemical characteristics in potato. Crop Sci. 49:949-954.

Gerami M, Fallah A, Khatami moghadam MR (2013). Study of potassium and sodium silicate on the morphological and chlorophyll content on the rice plant in pot experiment (Oryza sativa L.). Intl $J$ Agric Crop Sci4(10):658-661

Hattori T., Inanaga S., Araki H., An P., Morita S., Luxova M., Lux A. (2005). Application of silicon enhanced drought tolerance in sorghum bicolor. Physiologia Plantarum, 123: 459-466.

Hattori T., Inanaga S., Tanimoto E., Lux A., Luxova M., Sugimoto Y. (2003). Silicon-induced changes in viscoelastic properties of sorghum root cell walls. Plant Cell Physiology, 44: 743-749.

Huang HR, Xu L, Bokhtiar SM, Manoj KS, Li YR and Yang LT (2011). Effect of calcium silicate fertilizer on mycorrhiza and foliar spraying of some micronutrients $(\mathrm{Fe}+\mathrm{Mn}+\mathrm{Zn}$ ) and potassium silicate on enhancing salt tolerance of wheat plant. International Journal of Environment; 2:35-45.
Jafarei Y, Tabrizi EFM and Bybordi A (2015). Effect of different stages and times of silicon foliar spray on yield and yield components of bean. Science Journal; 36: 81-92.

Kaufman P.B., Takeoka Y., Carlson T.J., Bigelow W.C., Jones Ones J.D., Moore P.H., Ghosheh N.S. (1979). Studies on silica deposition in sugarcane (Saccharum spp.) using scanning electron microscopy, energy dispersive X-ray analysis, neutron activation analysis and light microscopy. Phytomorphology, 29:185-193.

Li Q.F., Ma C.C., Shang Q.L. (2007). Effects of silicon on photosynthesis and antioxidative enzymes of maize under drought stress. Chinese Journal of Applied Ecology, 18: 531-536.

Liang Y.C. (1998). Effects of silicon on leaf ultrastructure, chlorophyll content and photosynthetic activity in barley under salt stress. Pedosphere, 8: 289-296.

Lobato A.K.S., Coimbra G.K., Neto M.A.M., Costa R.C.L., Santos F.B.G., Oliveira C.F., Luz L.M., Barreto A.G.T., Pereira B.W.F., Alves G.A.R., Monterio B.S., Marochio C.A. (2009). Protective action of silicon on water relation and photosynthetic pigments in pepper plants induced to water deficit. Research Journal of Biological Sciences, 4: 617-623.

Ma J.F. (2004). Role of silicon in enhancing the resistance of plants to biotic and abiotic stresses. Soil Science and Plant Nutrition, 50: 11-18.

Morsy ASM and Mohamed NEM (2013). Using Silicon to Ameliorate the Deleterious Effects of Drought on Wheat (Triticum aestivum L.). Stem Cell; 4:1-8.

Noctor G., Veljvoic-Jovanovic S., Foyer C.H. (2000). Peroxide processing in photosynthesis: antioxidant coupling 
and redox signalling. Philosophical Transactions of the Royal Society of London, 355: 1465-1475.

Ren J, Guo J, Xing X, Qi G and Yuan ZL (2002). Preliminary study on yield increase effects and yield increase mechanism of silicate fertilizer on maize. J. of Maize Sci.; 10:86.

Sacala E. (2009). Role of silicon in plant resistance to water stress. Journal of Elementology, 14: 619-630.

Salim BBM, Eisa SS, Ibrahim IS, Girgis MGZ and Abdel-Rassoul M (2013). Effect of biofertilizers, soil characteristics, sugarcane nutrients and its yield parameters. J. South Agric.; 42:756-9.

Shen, X., Y. Zhou, L. Duan, Z. Li, A.E. Eneji, and J. Li. (2010). Silicon effects on photosynthesis and antioxidant parameters of soybean seedlings under droughtand ultraviolet-B radiation. J. Plant Phys. 167:1248-1252.

Singh K, Singh R, Singh JP, Singh Y, Singh KK (2006). Effect of level and time of silicon application on growth, yield and its polluted soils using crops of metal-accumulating plants. Resour Conserv Recyc., 11: 41- 49.

Sonobe, K., T. Hattorri, P. An, W. Tsuji, A.E. Eneji, S. Kobayashi, Y. Kawamura, K.Tanaka, and S. Inanaga. (2010). Effect of silicon application on sorghum root responses to water stress. J. Plant Nutr. 34:71-82.

Sritharan, N. and Mallika Vanangamudi (2006).Screening of rice genotypes for salt tolerance. Plant Archives 6: 81518.

Wang H, Li C and Liang Y (2001). Chapter 21 Agriculture utilization of silicon in China. Studies in Plant Science; 8:343358.

Zhu Z., Wei G., Li J., Qian Q., Yu J. (2004). Silicon alleviates salt stress and increases antioxidant enzymes activity in leaves of salt-stressed cucumber (Cucumis sativus L.). Plant Science, 167: 527-533.

\section{How to cite this article:}

Anitha, R., G. Gayathry, S. Thiruvarasan, P. Christy Nirmala Mary and Jayachandran, M. 2019. Techniques for Determination of Vitamin $B_{6}$, Vitamin $C$ and Variability in Areca Nut (Areca catechu) Samples of Karnataka, India. Int.J.Curr.Microbiol.App.Sci. 8(11): 1287-1301. doi: https://doi.org/10.20546/ijcmas.2019.811.152 